Web Jurnal:

http://ejournal.kemenperin.go.id/jli

\title{
Penggunaan katalis homogen dan heterogen pada proses hidrolisis pati umbi singkong karet menjadi glukosa
}

\section{The use of homogeneous and heterogeneous catalysts in hydrolysis process of rubber cassava starch into glucose}

\author{
Erti Praputri $^{1}$, Elmi Sundari* ${ }^{1}$, F Firdaus ${ }^{1}$, S Sofyan ${ }^{2}$ \\ 1. Jurusan Teknik Kimia Universitas Bung Hatta \\ Jalan Gajah mada No. 19 Olo Nanggolo, Padang, Indonesia \\ 2. Balai Riset dan Standardisasi Industri Padang \\ Jl. Raya LIK No. 23 Ulu Gadut Padang, Indonesia \\ * e-mail: elmisundari@yahoo.com
}

\begin{tabular}{l}
\hline INFO ARTIKEL \\
\hline Sejarah artikel: \\
Diterima \\
11 September 2018 \\
Direvisi \\
29 November 2018 \\
Diterbitkan \\
28 Desember 2018
\end{tabular}

Kata kunci: umbi singkong karet; katalis homogen; katalis heterogen; hidrolisis; bioetanol

\begin{abstract}
ABSTRAK
Singkong karet (Manihot glaziovii Muell) adalah salah satu sumber bahan baku bioetanol yang mempunyai kandungan pati yang cukup tinggi $(98,5 \%)$. Penelitian ini bertujuan mempelajari kinerja katalis $\mathrm{H}_{2} \mathrm{SO}_{4}, \mathrm{HCl}$, dan zeolit pada proses hidrolisis pati umbi singkong karet untuk menghasilkan glukosa. Proses hidrolisis untuk katalis homogen dilakukan pada temperatur $120^{\circ} \mathrm{C}$ dan volume asam $250 \mathrm{ml}$, sedangkan untuk katalis heterogen dengan rasio massa pati dan aquades (1:25), waktu 60 menit, dan temperatur $120^{\circ} \mathrm{C}$. Perolehan glukosa untuk katalis homogen diamati melalui variasi konsentrasi $\mathrm{HCl}$ dan $\mathrm{H}_{2} \mathrm{SO}_{4}$ masing-masing $(0,1 ; 0,15 ; 0,2 ; 0,25 ;$ dan $0,3 \mathrm{~N})$ dan waktu hidrolisis $(45 ; 60$; dan 75 menit). Untuk katalis heterogen, perolehan glukosa diamati melalui variasi massa zeolit (1; 3; dan $6 \mathrm{~g}$ ), jenis asam pengaktif $\mathrm{HCl}$ dan $\mathrm{H}_{2} \mathrm{SO}_{4}$ dengan konsentrasi $0,15 \mathrm{~N}$, dengan metode perendaman dan pemanasan pada temperature $50^{\circ} \mathrm{C}$. Hasil penelitian memperlihatkan konsentrasi dan waktu hidrolisis pati singkong karet berpengaruh terhadap perolehan glukosa pada penggunaan jenis katalis homogen $\left(\mathrm{H}_{2} \mathrm{SO}_{4}\right.$ dan $\left.\mathrm{HCl}\right)$. Glukosa tertinggi $(27,25 \%)$ diperoleh pada katalis homogen dengan konsentrasi $\mathrm{H}_{2} \mathrm{SO}_{4}$ $0,15 \mathrm{~N}$ dan waktu 60 menit. Zeolit yang diaktivasi dengan $\mathrm{HCl}$ dengan metode perendaman menghasilkan kadar glukosa lebih tinggi $(14,13 \%)$ daripada zeolit yang diaktifkan dengan $\mathrm{H}_{2} \mathrm{SO}_{4}(12,58 \%)$.
\end{abstract}

\begin{abstract}
Rubber cassava (Manihot glaziovii Muell) is one source of bioethanol raw material which has high starch content (98.5\%). The manufacture of bioethanol is carried out through the process of hydrolysis and fermentation. This research was aimed to study the performance of the homogeneous and heterogeneous catalysts in the hydrolysis process of starch from rubber cassava tubers to produce glucose. The hydrolysis process for homogeneous catalyst was carried out at a temperature $120^{\circ} \mathrm{C}$ and $250 \mathrm{ml}$ acid volume, while for heterogeneous catalyst was the ratio of starch mass and distilled water (1:25), 60 minutes time, and $120^{\circ} \mathrm{C}$ temperature. The glucose obtained for heterogeneous catalyst was observed through variations of $\mathrm{HCl}$ and $\mathrm{H}_{2} \mathrm{SO}_{4}$ concentrations $(0.1 ; 0.15$; 0.2; 0.25; and $0.3 \mathrm{~N}$ ) and hydrolysis time (45; 60; and 75 minutes). For heterogeneous catalyst, the glucose obtained was observed through zeolite mass variations (1;3; and 6 g), type of activating acid $\mathrm{HCl}$ and $\mathrm{H}_{2} \mathrm{SO}_{4}$ with $0.15 \mathrm{~N}$ concentration by immersion and heating method at $50^{\circ} \mathrm{C}$. The results showed that the concentration and hydrolysis time of rubber cassava starch affected the glucose obtained in the use of homogeneous catalyst types $\left(\mathrm{H}_{2} \mathrm{SO}_{4}\right.$ and $\left.\mathrm{HCl}\right)$. The highest glucose was obtained at $0.15 \mathrm{~N}$ acid concentrations and 60 minutes time. Zeolite which was activated with $\mathrm{HCl}$ with soaking method resulted in higher glucose levels (14.13\%) than activated with $\mathrm{H}_{2} \mathrm{SO}_{4}(12.58 \%)$.
\end{abstract}




\section{Pendahuluan}

Pati adalah karbohidrat yang berbentuk polisakarida yang terdapat dalam bahan nabati (Mastuti and Setyawardhani, 2010). Singkong karet (Manihot glaziovii Muell) adalah salah satu tanaman dengan kadar pati $98,47 \%$ yang tidak dimanfaatkan sebagai makanan karena mengandung unsur kimia asam sianida (HCN) yang bersifat racun (Firdausi et al., 2013). Umbi singkong karet dapat dijadikan salah satu sumber bahan baku untuk menghasilkan glukosa yang nantinya dikonversi menjadi bioetanol. Konversi pati menjadi glukosa dilakukan melalui proses hidrolisis (Hapsari and Phramashinta, 2013).

Hidrolisis adalah reaksi kimia antara air dengan suatu zat lain yang menghasilkan satu zat baru atau lebih dan juga menyebabkan suatu larutan terdekomposisi dengan menggunakan air. Reaksi hidrolisis pada umumnya merupakan reaksi endoterm (memerlukan kalor). Proses hidrolisis pati mengikuti persamaan 1 .

$$
\begin{aligned}
& \underset{\text { Pati }}{\left(\mathrm{C}_{6} \mathrm{H}_{10} \mathrm{O}_{5}\right) \mathrm{n}+\mathrm{n} \mathrm{H}_{2} \mathrm{O}} \longrightarrow \begin{array}{l}
\mathrm{nC}_{6} \mathrm{H}_{12} \mathrm{O}_{6} \\
\text { Glukosa }
\end{array} \\
& \text { Air }
\end{aligned}
$$

Proses hidrolisis dipengaruhi oleh beberapa parameter antara lain suhu reaksi, waktu reaksi, pencampuran pereaksi, konsentrasi asam (katalis), dan kadar suspensi pati (Mastuti and Setyawardhani, 2010). Proses hidrolisis berlangsung sangat lambat, sehingga dibutuhkan zat lain (katalis). Katalis adalah suatu zat yang mempercepat laju reaksi kimia pada suhu tertentu dengan menurunkan energi aktivasi, tanpa mengalami perubahan atau dikonsumsi oleh reaksi itu sendiri (Sylvia et al., 2015).

Jenis katalis yang sering digunakan pada proses hidrolisis pati oleh peneliti sebelumnya adalah katalis homogen, heterogen, dan enzim. Katalis homogen adalah jenis katalis yang mempunyai fasa yang sama dengan reaktan. Katalis heterogen adalah jenis katalis yang mempunyai fase yang tidak sama dengan reaktan. Jenis katalis homogen yang banyak digunakan adalah katalis asam $\left(\mathrm{HCl}, \mathrm{H}_{2} \mathrm{SO}_{4}\right.$, dan $\left.\mathrm{HNO}_{3}\right)$, sedangkan jenis katalis heterogen adalah zeolit. Reaksi katalitik mengikuti persamaan reaksi 2-4.

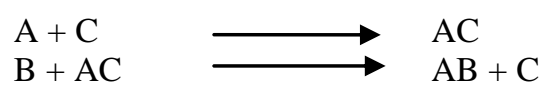

$\mathrm{B}+\mathrm{AC}$ $\mathrm{AB}+\mathrm{C}$

Meskipun katalis (C) terkonsumsi oleh reaksi 2, namun oleh reaksi 3 terbentuk kembali, sehingga untuk reaksi keseluruhannya menjadi seperti reaksi 4.

$$
\mathrm{A}+\mathrm{B}+\mathrm{C} \longrightarrow \mathrm{AB}+\mathrm{C}
$$

Katalis homogen mempunyai keunggulan, yaitu tidak mudah teracuni oleh kotoran dan setiap molekul katalis berfungsi aktif sebagai katalis. Kerugian katalis homogen diantaranya sulit dipisahkan dari campurannya dan mudah terurai pada temperatur tinggi. Dibandingkan katalis homogen, katalis heterogen memiliki kelebihan diantaranya dapat dipisahkan dari campuran reaksi hanya dengan cara penyaringan, sehingga mudah diregenerasi. Katalis heterogen juga mempunyai kekurangan yaitu jika permukaan katalis telah jenuh oleh molekul reaktan, maka reaksi tidak dapat dilanjutkan. Kejenuhan katalis dapat diatasi dengan melakukan regenerasi (Purnami et al., 2015). Penelitian tentang pengaruh konsentrasi katalis asam $\left(\mathrm{HCl}, \mathrm{H}_{2} \mathrm{SO}_{4}\right)$, dan waktu reaksi juga telah dilakukan diantaranya oleh (Mastuti and Setyawardhani, 2010) dan (Muhaimin et al., 2017) menemukan peningkatan konsentrasi katalis akan meningkatkan kadar glukosa. Hal ini disebabkan konstanta kecepatan reaksi hidrolisis berbanding lurus dengan konsentrasi $\mathrm{H}$ pada suasana asam (Irawan and Arifin, 2012). Pengaruh waktu hidrolisis terhadap perolehan glukosa juga telah diteliti oleh (Mastuti and Setyawardhani, 2010), yang menyatakan semakin lama waktu proses hidrolisis, maka kadar glukosa juga meningkat sampai waktu 120 menit. Setelah itu kenaikan kadar glukosa tidak terlalu signifikan.

Zeolit merupakan mineral hasil tambang yang bersifat lunak dan mudah kering. Warna dari zeolit adalah putih keabu-abuan, putih kehijau-hijauan, atau putih kekuning-kuningan. Ukuran kristal zeolit kebanyakan tidak lebih dari 10-15 mikron. Mineral ini memiliki kekhasan ketika berada dalam pemanasan terlihat seperti mendidih karena molekulnya kehilangan air dengan sangat cepat. Zeolit terdiri dari senyawa zat kimia alumino-silikat berhidrat dengan kation natrium, kalium, dan barium. Secara umum, Zeolit memiliki melekular sruktur yang unik, dimana atom silikon dikelilingi oleh 4 atom oksigen sehingga membentuk semacam jaringan dengan pola yang teratur (Lestari, 2010).

Zeolit memiliki sifat kimia dan fisika diantaranya mampu menyerap zat organik maupun anorganik. Selain berfungsi sebagai penukar kation dan katalis, zeolit alam pada umumnya mempunyai kristalinitas yang tidak terlalu tinggi, ukuran porinya sangat tidak seragam, aktivitas kalitik rendah, dan banyak mengandung pengotor seperti $\mathrm{Na}, \mathrm{K}, \mathrm{Ca}, \mathrm{Mg}$, dan Fe (Pardoyo et al., 2009). Keberadaan pengotor tersebut dapat mengurangi aktivitas zeolit. Agar peran zeolit dapat ditingkatkan perlu dilakukan aktivasi dan modifikasi. Selain untuk menghilangkan pengotor-pengotor yang terdapat pada zeolit alam, proses aktivasi zeolit juga ditujukan untuk memodifikasi sifat-sifat dari zeolit, seperti luas permukaan dan keasaman. Luas permukaan dan keasaman yang meningkat akan menyebabkan aktivitas katalitik dari zeolit meningkat. Salah satu kelebihan dari zeolit adalah memiliki luas permukaan dan keasaman yang mudah dimodifikasi (Hajar et al., 2016).

Penelitian tentang proses hidrolisis pati yang berasal dari umbi singkong karet telah dilakukan diantaranya menggunakan enzim (saccaromyces cereviae) dengan metode simultaneous saccarification fermentation, yaitu proses hidrolisis dan fermentasi dilakukan bersamaan (Hapsari and Phramashinta, 2013). Penggunaan enzim pada proses yang sama juga dilakukan oleh (Firdausi et al., 2013) dan (Arifwan et al., 2016). Sampai saat ini penggunaan katalis pada proses hidrolisis asam untuk bahan singkong karet belum banyak diteliti. Demkian juga penggunaan katalis heterogen (zeolit) belum dilakukan.

Penelitian ini bertujuan mempelajari kinerja katalis melalui konsentrasi dan waktu untuk katalis homogen, 
dan massa zeolit untuk katalis heterogen pada proses hidrolisis pati dari umbi singkong karet menjadi glukosa.

\section{Metode}

Bahan utama yang digunakan pada penelitian ini adalah tepung pati umbi singkong karet, air, dan zeolit. Bahan pendukung antara lain $\mathrm{HCl}$ dan $\mathrm{H}_{2} \mathrm{SO}_{4}$. Bahan untuk analisis kadar glukosa yaitu $\mathrm{NaOH}, \mathrm{Na}_{2} \mathrm{~S}_{2} \mathrm{O}_{3}, \mathrm{KI}$, dan larutan luff-schoorl. Proses hidrolisis berlangsung dalam autoclave. Pemisahan dan analisis glukosa dilakukan dalam peralatan gelas. Zeolit yang diaktivasi berbentuk $\mathrm{H}$-Zeolit yang akan digunakan sebagai katalis pada proses hidrolisis pati umbi singkong karet menjadi glukosa.

\subsection{Variasi perlakuan}

Jenis katalis yang digunakan adalah katalis homogen $\left(\mathrm{HCl}\right.$ dan $\mathrm{H}_{2} \mathrm{SO}_{4}$ ) dan heterogen (Zeolit). Proses hidrolisis untuk katalis homogen dilakukan pada suhu $120^{\circ} \mathrm{C}$ dan volume $250 \mathrm{ml}$. Perolehan glukosa untuk katalis homogen diamati melalui variasi konsentrasi $\mathrm{HCl}(0,1 ; 0,15 ; 0,2 ; 0,25 ;$ dan $0,3 \mathrm{~N})$, konsentrasi $\mathrm{H}_{2} \mathrm{SO}_{4}(0,1 ; 0,15 ; 0,2 ; 0,25$; dan $0,3 \mathrm{~N})$, dan waktu hidrolisis $(45 ; 60$; dan 75 menit). Proses dengan katalis heterogen dilakukan dengan rasio massa pati dan aquades (1:25), waktu 60 menit, dan suhu $120^{\circ} \mathrm{C}$. Untuk katalis heterogen, perolehan glukosa diamati melalui variasi massa zeolit $(1 ; 3$; dan 6 gram). Jenis asam pengaktif adalah $\mathrm{HCl}$ dan $\mathrm{H}_{2} \mathrm{SO}_{4}$. Konsentrasi asam yang akan digunakan adalah konsentrasi asam optimum dari proses hidrolisis katalis homogen. Pengaktifan zeolit dilakukan dengan metode perendaman dalam asam dan pemanasan zeolit dengan asam pada suhu $50^{\circ} \mathrm{C}$.

\subsection{Prosedur percobaan}

Penelitian dilakukan dengan 3 tahap yaitu persiapan pati singkong karet, aktivasi zeolit, dan proses hidrolisis. Analisis kadar glukosa dilakukan dengan metode luffschoorl.

\subsubsection{Persiapan pati}

Persiapan pati dilakukan dalam beberapa tahap yaitu pembersihan, pengupasan, dan pemarutan. Pati yang diperoleh dilakukan proses ekstraksi pati dengan perbandingan pati : air (1 : 3) dan dilakukan pengadukan. Pemisahan ekstrak (pati basah) dari larutan ekstrak dengan menggunakan penyaringan. Pati basah kemudian dikeringkan menggunakan panas sinar matahari, lalu dihitung kadar pati kering.

\subsubsection{Aktivasi zeolit}

Zeolit diaktifkan dengan menggunakan metode perendaman dan pemanasan. Untuk kedua metode, jumlah zeolit yang akan diaktifkan ditimbang sebanyak 50 gram, dimasukkan ke dalam cawan penguap dan ditambahkan $\mathrm{H}_{2} \mathrm{SO}_{4} 0,15 \mathrm{~N}$. Untuk metode perendaman dan pemanasan, $\mathrm{H}_{2} \mathrm{SO}_{4}$ yang ditambahkan harus sampai merendam zeolit. Waktu yang dibutuhkan untuk mengaktifkan zeolit menggunakan metode pemanasan adalah 30 menit dan suhu $50^{\circ} \mathrm{C}$. Metode perendaman dilakukan pada suhu ruang dan waktu 30 menit. Zeolit yang telah direndam dan dipanaskan kemudian dicuci menggunakan air dimasukkan ke dalam oven pada suhu $130^{\circ} \mathrm{C}$ dan waktu 3 jam. Zeolit yang diperoleh berbentuk $\mathrm{H}$-Zeolit yang akan digunakan sebagai katalis pada proses hidrolisis pati umbi singkong karet menjadi glukosa.

\subsubsection{Proses hidrolisis}

Proses hidrolisis dilakukan dengan menggunakan katalis homogen dan katalis heterogen.

\section{Proses hidrolisis dengan katalis homogen}

Proses hidrolisis untuk katalis homogen dilakukan melalui tahapan berikut. Tepung pati umbi singkong karet ditimbang sebanyak 25 gram dan dimasukkan ke dalam erlenmeyer $500 \mathrm{ml}$. $\mathrm{HCl} 0.1 \mathrm{~N}$ sebanyak $250 \mathrm{ml}$ ditambahkan dan diaduk sampai homogen. Kemudian ditutup dengan aluminium foil dan dimasukkan ke dalam autoclave untuk proses hidrolisis. Proses hidrolisis dilakukan pada suhu $120^{\circ} \mathrm{C}$ dan dibiarkan selama 60 menit. Setelah tercapai 60 menit autoclave dimatikan dan didinginkan sampai suhu kamar $\left(25-30^{\circ} \mathrm{C}\right)$. Erlenmeyer dikeluarkan dari autoclave dan dilakukan pemisahan hasil hidrolisis (larutan glukosa dan sisa sampel yang tidak terhidrolisis) dengan penyaringan. Tahapan ini diulangi untuk variabel lainnya.

\section{Proses hidrolisis dengan katalis heterogen}

Larutan pati dan aquadest dengan perbandingan 1:25 sebanyak $100 \mathrm{ml}$ dimasukkan ke dalam erlenmeyer 250 ml. Zeolit alam yang telah aktif ditambahkan sesuai dengan variabel dan diaduk sampai homogen. Erlenmeyer kemudian ditutup dengan aluminium foil dan dimasukkan ke dalam autoclave untuk proses hidrolisis. Proses hidrolisis dilakukan pada suhu $120^{\circ} \mathrm{C}$ dan dibiarkan selama 60 menit. Autoclave selanjutnya dimatikan dan didinginkan sampai suhu kamar (25$30^{\circ} \mathrm{C}$ ). Erlenmeyer dikeluarkan dari autoclave dan dilakukan penyaringan untuk memisahkan filtrat (larutan hasil hidrolisis) dan sisa sampel yang tidak terhidrolisis.

\subsubsection{Analisis kadar glukosa}

Analisis kadar glukosa dilakukan melalui tahapan berikut ini. Filtrat hasil hidrolisis diambil sebanyak 1 $\mathrm{ml}$, dimasukan ke dalam erlenmeyer $250 \mathrm{ml}$ dan ditambahkan $25 \mathrm{ml}$ larutan luff-schoorl. Kemudian $15 \mathrm{ml}$ aquadest dan 3 tetes $\mathrm{NaOH} 30 \%$ ditambahkan ke dalam erlenmeyer dan dipanaskan dengan hot plate. Pemanasan dilakukan sampai mendidih selama 5 menit. Erlenmeyer didinginkan menggunakan air mengalir dan ditambahkan $25 \mathrm{ml} \mathrm{H} \mathrm{SO}_{4} 25 \%$ dan $15 \mathrm{ml}$ larutan $\mathrm{KI} 20 \%$ secara perlahan-lahan. Larutan dititrasi dengan $\mathrm{Na}_{2} \mathrm{~S}_{2} \mathrm{O}_{3} 0,1 \mathrm{~N}$ sampai warna kuning muda, ditambahkan indikator amilum $1 \%$ (terbentuk warna biru tua) dan proses titrasi 
dilanjutkan sampai warna biru tua hilang. Pengujian dilakukan dengan menggunakan persamaan 5 .

$$
\text { Angka Tabel (glukosa) }=\frac{(B m l-A m l) x N a_{2} S_{2} o_{g}}{0.1}
$$

Keterangan:

Angka tabel : kandungan glukosa dalam sample

$\mathrm{B} \mathrm{ml} \mathrm{:} \mathrm{volume} \mathrm{titrasi} \mathrm{blanko}$

A ml : volume titrasi larutan sample

$\mathrm{N} \mathrm{Na}_{2} \mathrm{~S}_{2} \mathrm{O}_{3} \quad$ : normalitas larutan penitrasi

$0,1 \quad$ normalitas $\mathrm{Na}_{2} \mathrm{~S}_{2} \mathrm{O}_{3}$ di tabel luff schrool

\section{Hasil dan pembahasan}

\subsection{Katalis homogen}

Hidrolisis yang berlangsung dalam suasana asam menghasilkan pemecahan ikatan glikosida (Dewi et al., 2014) melalui 3 tahap. Pertama, proton yang berperan sebagai katalisator asam berinteraksi dengan oksigen glikosida yang menghubungkan 2 unit glukosa membentuk asam konjugat. Selanjutnya diikuti dengan pemecahan yang lambat dari ikatan C-O, menghasilkan zat antara kation karbonium siklis. Akhirnya kation karbonium mengadisi molekul air dengan cepat membentuk hasil akhir yang stabil dan melepaskan proton (Mardina et al., 2014). Mekanisme reaksi hidrolisis dicantumkan pada Gambar 1.

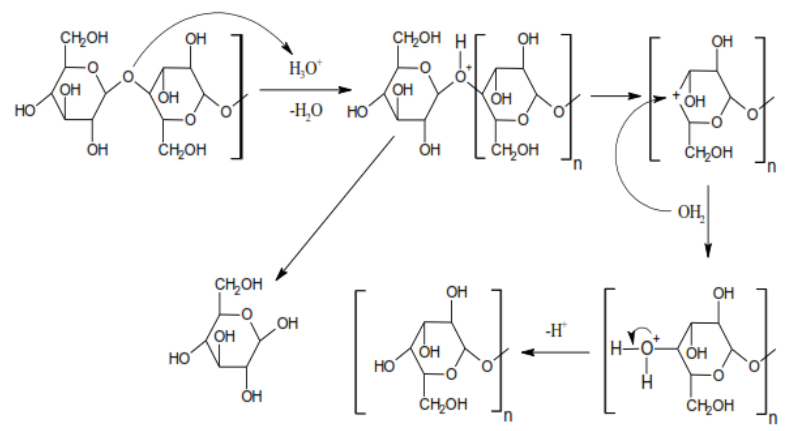

Gambar 1. Mekanisme reaksi hidrolisis polisakarida (pati). Sumber: (Minarni et al., 2013)

\subsubsection{Pengaruh konsentrasi $\mathrm{HCl}$ dan $\mathrm{H}_{2} \mathrm{SO}_{4}$ terhadap kadar glukosa}

Gambar 2 memperlihatkan, pengaruh konsentrasi terhadap kadar glukosa pada katalis $\mathrm{HCl}$ dan $\mathrm{H}_{2} \mathrm{SO}_{4}$ memiliki pola yang sama, Untuk kedua jenis asam, kadar glukosa meningkat pada konsentrasi 0,1 - 0,2 N. dimana kadar glukosa tertinggi untuk kedua jenis katalis diperoleh pada konsentrasi katalis 0,15 N. Kadar glukosa yang diperoleh dengan menggunakan katalis $\mathrm{H}_{2} \mathrm{SO}_{4}$ adalah $27,25 \%$. Hasil ini lebih tinggi dibandingkan dengan kadar glukosa yang diperoleh dari penggunaan katalis $\mathrm{HCl}$ yaitu 23,53\%. Hal ini disebabkan $\mathrm{H}_{2} \mathrm{SO}_{4}$ memiliki jumlah ion $\mathrm{H}^{+}$lebih banyak dari $\mathrm{HCl}$. Semakin tinggi konsentrasi katalis, semakin banyak ion $\mathrm{H}^{+}$yang tersedia untuk memutuskan ikatan glikosida pada pati sehingga semakin cepat terjadi reaksi (Juwita et al., 2012). Pada konsentrasi katalis 0,2-0,3 N kadar glukosa mengalami penurunan. Hal ini disebabkan konsentrasi katalis yang terlalu tinggi, mengakibatkan glukosa dan senyawa gula lainnya terdegradasi menjadi senyawa hidroksi metil furfural (HMF) dan furfural akan membentuk asam formiat yang akan menjadi inhibitor untuk proses hidrolisis lanjutan (Muin et al., 2014). Konversi glukosa menjadi Hidroksimetil Furfural dicantumkan dalam Gambar 3.

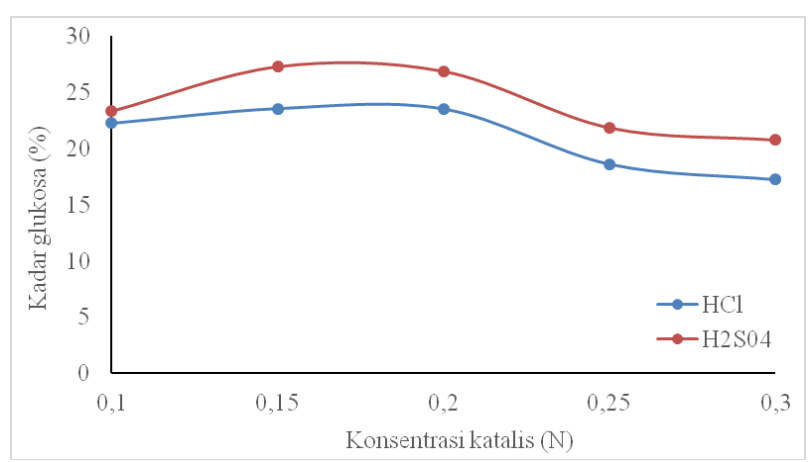

Gambar 2. Hubungan konsentrasi katalis dan kadar glukosa

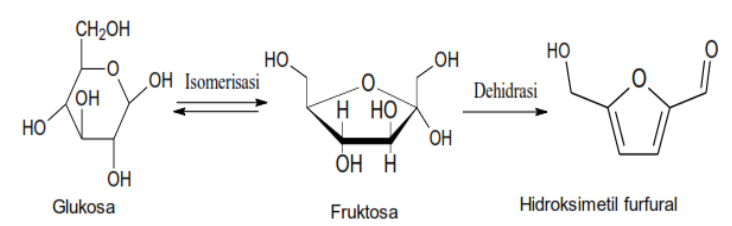

Gambar 3. Konversi glukosa menjadi Hidroksimetil furfural. Sumber: (Obed et al., 2015)

Peneliti lain juga mengatakan, semakin tinggi kosentrasi katalis menyebabkan tumbukan antar reaktan akan semakin besar sehingga kadar glukosa yang dihasilkan juga semakin besar.

\subsubsection{Pengaruh waktu hidrolisis terhadap kadar glukosa}

Pada prinsipnya semakin lama waktu hidrolisis maka semakin tinggi kadar glukosa yang terbentuk. Semakin lama waktu hidrolisis semakin mempercepat dekomposisi glukosa (Dewi et al., 2014).

Hal ini sedikit berbeda dengan yang terlihat pada Gambar 4. Kadar glukosa meningkat mulai dari waktu 45 sampai waktu 60 menit, setelah itu terjadi penurunan perolehan sampai 75 menit. Kadar glukosa maksimum diperoleh 27,25\% untuk katalis $\mathrm{H}_{2} \mathrm{SO}_{4}$ dan 23,53\% untuk katalis $\mathrm{HCl}$. Hasil ini sesuai dengan penelitian yang dilakukan oleh (Melwita and Kurniadi, 2014). Untuk katalis $\mathrm{H}_{2} \mathrm{SO}_{4}$ waktu maksimum yang dicapai juga 60 menit. Namun kadar glukosa lebih tinggi yaitu 49,25\%.

Pengaruh waktu hidrolisis juga telah dipelajari oleh (Mastuti and Setyawardhani, 2010) yang menemukan waktu pengontakan optimum untuk katalis asam $(\mathrm{HCl})$ adalah 60 menit dengan kadar glukosa 2,88 mg/ml pada konsentrasi $\mathrm{HCl} 0,15 \mathrm{~N}$. Hasil penelitian juga menunjukkan waktu optimum yang diperoleh adalah 60 menit untuk konsentrasi $\mathrm{HCl} 0,15 \mathrm{~N}$ dengan kadar glukosa 23,53\%. Perbedaan kadar glukosa yang diperoleh dipengaruhi oleh kadar pati yang ada di dalam sampel. 


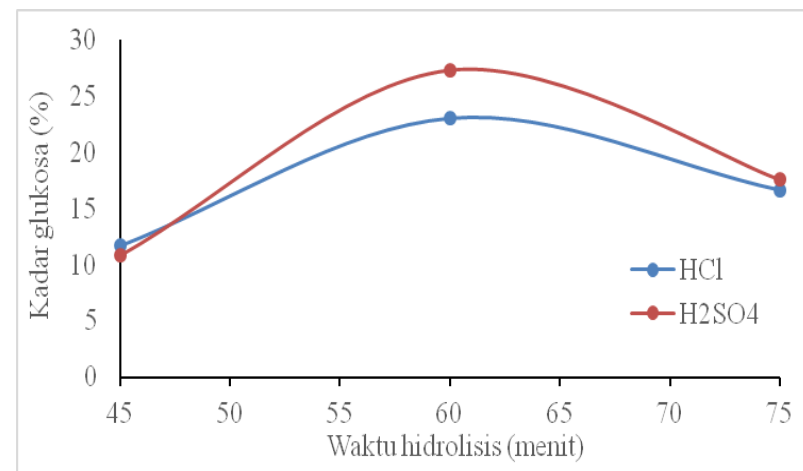

Gambar 4. Hubungan waktu hidrolisis dan kadar glukosa

\subsection{Katalis heterogen (zeolit)}

Hasil penelitian dengan menggunakan katalis heterogen dapat dilihat pada Gambar 5 dan 6. Kedua gambar memperlihatkan kinerja katalis zeolit yang telah diaktivasi dengan $\mathrm{HCl} 0,15 \mathrm{~N}$ dan $\mathrm{H}_{2} \mathrm{SO}_{4}$ 0,15 $\mathrm{N}$ dengan menggunakan panas dan perendaman. Dari Gambar 5 dapat dilihat bahwa kadar glukosa dengan menggunakan zeolit teraktivasi $\mathrm{HCl}$ memberikan perbedaan yang signifikan. Zeolit yang diaktifkan dengan menggunakan panas menghasilkan kadar glukosa yang lebih rendah daripada yang diaktifkan tanpa menggunakan panas. Pada massa zeolit yang sama (3 g) kadar glukosa tanpa pemanasan menghasilkan glukosa dengan kadar 14,13\%, sedangkan dengan pemanasan $1,78 \%$.

Demikian juga halnya pada penggunaan $\mathrm{H}_{2} \mathrm{SO}_{4}$ memperlihatkan hasil yang sama. Kadar glukosa dengan perendaman $12,58 \%$, sedangkan dengan pemanasan $4,42 \%$. Hal ini disebabkan panas yang diberikan untuk aktivasi zeolit tidak stabil sehingga tidak seluruh porositas zeolit teraktivasi (Dewi et al., 2014). Selain itu, aktivasi zeolit melalui perendaman dalam $\mathrm{HCl}$ dengan tujuan menghilangkan logam pengotor serta material lain yang terdapat dalam pori zeolit mengakibatkan zeolit kaya akan hidrogen (zeolit-H) dan atom $\mathrm{H}$ mudah tertukar dengan kation lain. Perlakuan ini akan mengurangi jumlah aluminium di kerangka maupun di permukaan pori sehingga terbukanya pori zeolit yang tertutupi oleh pengotor organik dan luas permukaan zeolit akan semakin meningkat (Nurhayati and Utomo, 2016).

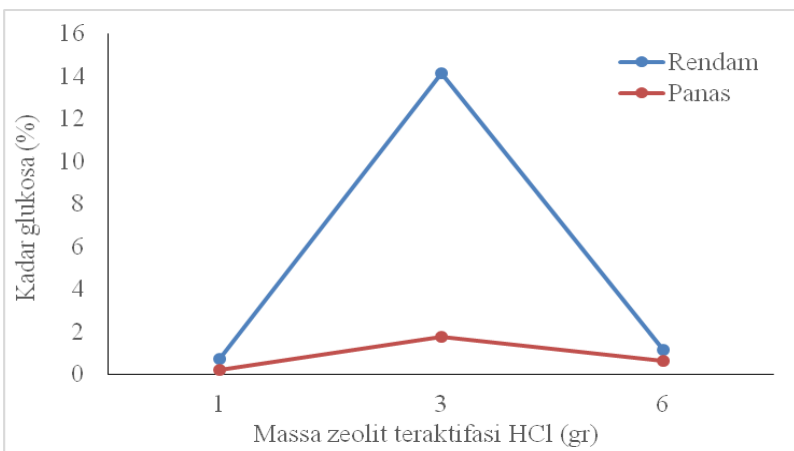

Gambar 5. Hubungan massa katalis zeolit (aktivasi $\mathrm{HCl}$ ) terhadap kadar glukosa

Gambar 6 memperlihatkan kadar glukosa yang dihasilkan oleh zeolit yang diaktifkan dengan $\mathrm{H}_{2} \mathrm{SO}_{4}$. Pola glukosa yang dihasilkan sama dengan menggunakan $\mathrm{HCl}$. Kadar maksimum glukosa pada penggunaan massa zeolit $3 \mathrm{~g}$ adalah $12,58 \%$. Kadar glukosa yang dihasilkan lebih rendah dari yang dihasilkan oleh zeolit yang diaktifkan dengan $\mathrm{HCl}$. Hal ini disebabkan oleh molekul $\mathrm{H}_{2} \mathrm{SO}_{4}$ lebih besar dari pada molekul $\mathrm{HCl}$ sehingga tidak semua molekul $\mathrm{H}_{2} \mathrm{SO}_{4}$ dapat menempati pori yang terdapat pada zeolit. Akibatnya aktivasi zeolit tidak sempurna (Mardina et al., 2014). Penurunan ini juga dapat disebabkan suhu yang tidak stabil selama proses hidrolisis. Suhu membawa dampak yang lebih signifikan dibandingkan dengan dampak yang dibawa oleh katalis (riskatama, 2013).

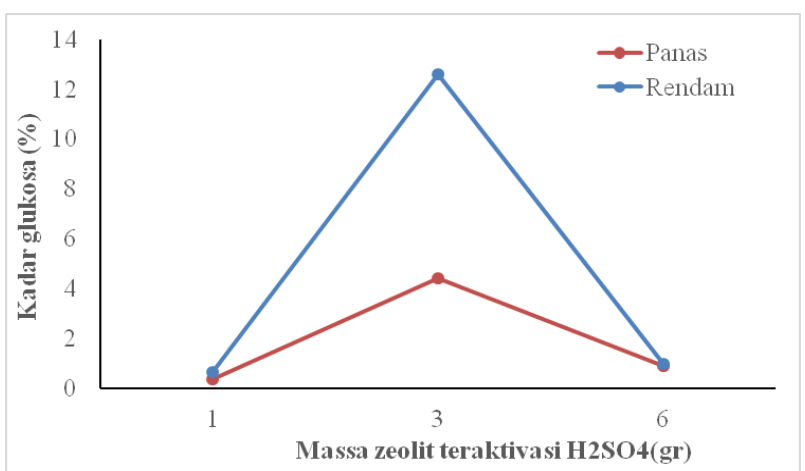

Gambar 6. Hubungan massa katalis zeolit (aktivasi $\mathrm{H}_{2} \mathrm{SO}_{4}$ ) terhadap kadar glukosa

Dari Tabel 1 dapat dilihat bahwa reaksi hidrolisis tanpa katalis memberikan kadar glukosa yang rendah yaitu $2,73 \%$. Hal ini disebabkan waktu yang dibutuhkan untuk melewati energi aktivasi lebih lama. Penggunaan katalis, mengurangi energi aktivasi sehingga reaksi dapat berlangsung lebih cepat dan kadar glukosa lebih tinggi. Pada prinsipnya, hidrolisis pati adalah pemutusan rantai polimer pati menjadi unit-unit glukosa $\left(\mathrm{C}_{6} \mathrm{H}_{12} \mathrm{O}_{6}\right)$ (Muin et al., 2014). Proses ini berlangsung lambat sehingga dibutuhkan katalis untuk mempercepat reaksinya.

Tabel 1

Kadar glukosa optimum pada masing-masing perlakuan.

\begin{tabular}{ll}
\hline Jenis katalis & Kadar glukosa (\%) \\
\hline Tanpa katalis (kontrol) & 2,73 \\
$\mathrm{HCl} \mathrm{0,15} \mathrm{N}$ & 23,53 \\
$\mathrm{H}_{2} \mathrm{SO}_{4} 0,15 \mathrm{~N}$ & 27,25 \\
Zeolit & 14,13 \\
\hline
\end{tabular}

\section{Kesimpulan}

Konsentrasi dan waktu hidrolisis pati singkong karet mempengaruhi perolehan glukosa pada penggunaan jenis katalis homogen $\left(\mathrm{H}_{2} \mathrm{SO}_{4}\right.$ dan $\left.\mathrm{HCl}\right)$. Kadar glukosa tertinggi diperoleh pada konsentrasi $\mathrm{H}_{2} \mathrm{SO}_{4} 0,15 \mathrm{~N}$ dan waktu 60 menit. Kadar glukosa yang diperoleh dengan menggunakan katalis heterogen (zeolit) yang diaktivasi dengan menggunakan panas lebih rendah daripada zeolit yang diaktifkan dengan perendaman. Zeolit yang diaktivasi dengan $\mathrm{HCl}$ dan perendaman menghasilkan kadar glukosa lebih tinggi $(14,13 \%)$ dari pada zeolit yang diaktifkan dengan $\mathrm{H}_{2} \mathrm{SO}_{4}(12,58 \%)$. 


\section{Daftar pustaka}

Arifwan, A., Erwin, E., Kartika, R., 2016. Pembuatan bioetanol dari singkong karet (Manihot Glaziovii Muell) dengan hidrolisis enzimatik dan difermentasi menggunakan Saccharomyces Cerevisiae. J. At. 1, $10-12$.

Dewi, T.K., Monica, N., Novalita, S., 2014. Pembuatan bioetanol dari keladi liar melalui hidrolisis dengan katalis asam klorida dan fermentasi. J. Tek. Kim. 20, 7-13.

Firdausi, N.Z., Samodra, N.B., H, H., 2013. Pemanfaatan pati singkong karet (Manihot glaziovii) untuk produksi bioetanol fuel grade melalui proses distilasidehidrasi menggunakan zeolit alam. J. Teknol. Kim. dan Ind. 2, 76-81.

Hajar, E.W.I., Ungsiono, T.A., Utomo, S., Bayu, S., 2016. Proses hidrolisis menggunakan katalis zeolit alam pada kulit pisang kepok sebagai sumber glukosa. J. Integr. Proses 6, 28-32.

Hapsari, M.A., Phramashinta, A., 2013. Pembuatan bioetanol dari singkong karet (Manihot glaziovii) untuk bahan bakar kompor rumah tangga sebagai upaya mempercepat konversi minyak tanah ke bahan bakar nabati. J. Teknol. Kim. dan Ind. 2, 240-245.

Irawan, D., Arifin, Z., 2012. Proses hidrolisis sampah organik menjadi gula dengan katalis asam 1, 1-6.

Juwita, R., Syarif, L.R., Tuhuloula, A., 2012. Pengaruh jenis dan konsentrasi katalisator asam terhadap sintesis furfural dari sekam padi. Konversi 1, 34-38.

Lestari, D.Y., 2010. Kajian modifikasi dan karakterisasi zeolit alam dari berbagai negara, in: Prosiding Seminar Nasional Kimia Dan Pendidikan Kimia 2010.

Mardina, P., Phratama, H.A., Hayati, D.M., 2014. Pengaruh waktu hidrolisis dan konsentrasi katalisator asam sulfat terhadap sintesis furfural dari jerami padi. Konversi 3, 1-8.
Mastuti, E., Setyawardhani, D.A., 2010. Pengaruh variasi temperatur dan konsentrasi katalis pada kinetika reaksi hidrolisis tepung kulit ketela pohon. Ekulibrium 9, 23-27.

Melwita, E., Kurniadi, E., 2014. Pengaruh waktu hidrolisis dan konsentrasi $\mathrm{H} 2 \mathrm{SO} 4$ pada pembuatan asam oksalat dari tongkol jagung. Tek. Kim. 20, 5563.

Minarni, N., Ismuyanto, B., Sutrisno, 2013. Pembuatan bioetanol dengan bantuan Saccharomyces cerevisiae dari glukosa hasil hidrolisis biji durian (Durio zhibetinus). Kim. Student J. 1, 36-42.

Muhaimin, M., Wiyantoko, B., Putri, R.N., Rusitasari, R., Ruwindya, Y., 2017. Penentuan kadar glukosa pada reaksi hidrolisis daun nanas dengan katalis dan tanpa katalis H2SO4. pp. 185-189.

Muin, R., Lestari, D., Sari, T.W., 2014. Pengaruh konsentrasi asam sulfat dan waktu fermentasi terhadap kadar bioetanol yang dihasilkan dari biji alpukat. J. Tek. Kim. 20, 1-7.

Nurhayati, N.D., Utomo, S.B., 2016. Modifikasi zeolit alam sebagai katalis melalui pengembangan logam tembaga, in: Seminar Nasional Kimia Dan Pendidikan Kimia VIII. pp. 222-226.

Obed, O., Alimuddin, A.H., Harlia, 2015. Optimasi katalis asam sulfat dan asam maleat pada produksi gula pereduksi dari hidrolisis kulit buah durian. JKK 4, 67-74. doi:10.1111/all.12994

Pardoyo, P., Listiana, L., Darmawan, A., 2009. Pengaruh perlakuai $\mathrm{HCl}$ pada kristalinitas dan kemampuan adsorpsi zeolit alam terhadap ion $\mathrm{Ca} 2+$. J. Sains Mat. $17,100-104$.

Purnami, P., Wardana, I., K, V., 2015. Pengaruh pengunaan katalis terhadap laju dan efisiensi pembentukan hidrogen. J. Rekayasa Mesin 6, 51-59.

Sylvia, N., Meriatna, M., Haslina, H., 2015. Kinetika hidrolisa kulit pisang kepok menjadi glukosa menggunakan katalis asam klorida. J. Teknol. Kim. Unimal 2, 51-65. 